\title{
Cooperation and Coopetition as a Tools Which Could Improve Leading Startups all over the
} World

\author{
Aneta Ejsmont \\ Prof. Edward F. Szczepanik State Higher Vocational School in Suwalki, Department of Humanities- Economics
}

\begin{abstract}
Building own business is a long-term and laborious process. A person who leads a startup tries to start with building own business by taking first steps toward financial independence. Analyzing conditions in Poland, on average every second startup sells its services abroad, admittedly it is good news, although half of them do not export at all. Half of the startups which export their services and goods generates more than $50 \%$ of their revenues outside Poland. Very interesting is the fact that $60 \%$ of exporters have conducted their foreign sale since the moment of establishing their business. On which markets do they sell their services? It turns out that the most popular are markets in the European Union (54\%), including the United Kingdom 14\% and Germany $9 \%$. Only about $25 \%$ of Polish startups exports their products and services to the United States. Taking the United States into consideration, in 2008 the USA lost their leading position in the number of startups which are newly created and achieving success in business. Currently in terms of the number of new startups the USA is on a quite distant place after Denmark, Finland, Sweden, Hungary, New Zealand, Israel or Italy. In short, more companies were closed than created, so it was, as a matter of fact, like in Poland. Therefore, the condition to improve the development of startups both from Poland and other countries all the world is to increase cooperation and coopetition.
\end{abstract}

Keywords: cooperation, coopetition, company, startup

\section{Introduction}

The fashion for startups has been developing all over the world for a few years, also on the Polish market. This modern form of new enterprises or germinating ideas for venture is to stimulate economy and to induce a lot of people to set up their own business activity, for their own account. Cash is not necessary to set up a startup. Launching a startup also does not require funds regardless what the venture concerns, whether it is IT or any other trade idea. However, the idea itself may obscure a rational shattering it or preventing objective evaluation of the chances to succeed on the market. Obviously, even the most crazy ideas may be a success but the probability is rather small. Excessive belief in the success of the venture may hinder apparent threats and drawbacks, therefore the phase of searching and elaborating the project is essential. Building own enterprise is a long and laborious process. When analysing Poland's condition, yearly every second startup exports its products and services and half of them gets over $50 \%$ of their revenues from investments made outside Poland. In terms of other countries, when in Poland such ventures may only be closed, in the USA new, great projects start. Although also there in 2008, i.e. since the global financial crisis was spreading to a bigger scale, they lost their leading position in the number of newly started and successful enterprises.

Nowadays, according to the Gallup Organisation it is on far twelfth place behind such countries as Denmark, Finland, Sweden, Hungary, New Zealand, Israel or Italy. According to the US Census Bureau in 2014 for the first time crossed two curves: the number of start-ups and liquidated entities, i.e. more companies were closed than started. The criterion for startups is that they function and employ at least one employee. Till 2008 the number of startups was on average about 100,000 higher than liquidated firms. In 2014 400,000 companies were set up and 470,000 were closed ${ }^{1}$. Therefore, the

\footnotetext{
${ }^{1}$ M. Bengtsson, S. Kock (2000). Coopetition in Business Networks- Cooperate and Compete Simultaneously. Industrial Marketing Management, 29, 411; J. Cygler (2009). Kooperencja przedsiębiorstw. Czynniki sektorowe i korporacyjne. Warszawa: Szkoła Główna Handlowa w Warszawie, 15
} 
aim of this article is to try and verify the research hypothesis that cooperation connected with coopetition may positively influence the development of startups worldwide.

Cooperation is generally defined as joint action of at least two entities which is this way strive to a better realisation of their aims or achieving a common goal. Coopetition, on the other hand, is a process consisting in simultaneous clash of two contrary relation: competition and cooperation ${ }^{1}$.

It is cooperation connected with elements of competition that is necessary for the startups to stay in the market, i.e. rising startups should cooperate more with big corporations what may enable them to survive difficult situations connected with fluctuations of economic situation. Startups owners to transfer their activity to a higher level should mind the environment that surrounds them. Therefore, they ought to cooperate with other economic entities with similar goals and be surrounded by people who go in the same direction to build relations exceeding usual frameworks. Companies starting their economic activity should look for other companies which could provide mentor guidelines, support and inspiration.

\section{Research methodology}

In this elaboration was used research method including material analysis and synthesis. The applied method allowed to prove that the condition to improve the functioning of startups and at the same time their development both in Poland as well as worldwide is cooperation connected with coopetition which increase the chances to succeed in business.

The applied analysis is a statistical procedure allowing to quantitatively determine the influence of cooperation and coopetition on the level of startups development regarding their number in particular countries, innovation level, profitability, the number of clients and business partners. Material synthesis connects specified elements comprising the research problem which is low level of startups development in Poland in relation the rest of the world. In this case synthesis forms holistic cognitive treating of the analysed research problem in the process of conducting business activity. Therefore, this part of the research method is a specific combination with comparative analysis of business entities regarding the above mentioned factors.

The tool used in this article is the so called "standardized effect", i.e. the effect expressed in a convenient standardized units. Standardized effect for independent trials in conducting the $t$-tests is the difference of means divided by a standard deviation. In the analysis of the $t$-test effect size there are the following sections of the standardized effect ${ }^{2}$ :

- very small effect $(E s<0,20)$,

- small effect $(0,20-0,50)$,

- medium effect $(0,50-0,80)$,

- large effect (Es>0,80).

Comparing the amounts of the above economic magnitudes calculated for particular startups giving the basis to formulate alternative hypothesis confirming the fact how much cooperation in connection with coopetition contributes to improvement of their functioning enables more or less precise verification of the above hypothesis, however it does not allow to fully state whether the obtained results give optimal solution. Therefore, analysis and synthesis of material is essential to determine this.

\section{The problem of startup creation}

Startup is an enterprise which fulfils at least one of the two conditions ${ }^{3}$ :

1. It belongs to digital economy sector, what means that information processing or derived technologies comprise at least one or more of the key elements of its business model,

2. It creates new technological solutions in IT/ICT, i.e. connected with the Internet and information technologies.

1http://www.statsoft.pl/textbook/glosfra_stat.html?http\%3A\%2F\%2Fwww.statsoft.pl\%2Ftextbook\%2Fglose.html (August 12, 2016)

2 J. Picken (2017). From Startup to Scalable Enterprise: Laying the Foundation. Business Horizons, 60 Issue 5, 587-589

${ }^{3}$ K. Rockowood (2017). Is That Startup Spirit Sagging? You Can Build it Back Up. Inc, 39 Issue 7, 68 
As it was mentioned in the introduction, the fashion for start-ups has been developing for a few years and also on the Polish market there are more and more such initiatives. This modern form of newly created enterprise is to stimulate economy and to induce a lot of people to set up their own business activity, for their own account. Cash is not necessary to set up a startup. Launching a startup also does not require funds regardless what the venture concerns, whether it is IT or any other trade idea.

Owing to zero investments in the market examination and at the same time receivers' expectations, one my expand their knowledge and gain new skill and experience without losing money if the idea turns out to be unsuccessful. If the venture fails, one may gain by saving on investments. It is also some kind of a motivation and determination test to project implementation. However, as it turns out, nothing comes easy and even the best ideas require adjustments to receivers' needs. Besides being the persistence and patience test, time devoted for communication and collecting market data together with their analysis is a test for creativity and flexibility towards one's ideas. No financial outlays are necessary on this stage for the idea to evolve, but searching investors who would like to put financial means into a rising enterprise is of key importance. Very often at this stage the idea becomes profitable, even certain of success or requires taking risk due to the market dynamic and too many independent factors. In the first case, investors will find themselves. Owing to a lot of research and pilot tests of products, the startup becomes known and often even recognisable, in demand. To its development only capital is necessary'.

Every year there are many competitions for startups. On the Polish market there are a few organisations of this kind, such as ${ }^{2}$ :

- Lewiatan Business Angels,

\section{- Amber Business Angels Network or}

- Supraregional Business Angels Network - Innovation.

Besides private investors, foundations created to support entrepreneurship and also EU funds for innovative ventures are a popular form of startups funding. JEREMIE, created by the European Commission, the European Investment Fund and European Investment Bank, is one of such funds. Also government financial resources may be useful. There are grants from District Employment Agencies for launching own business activity. Means from assistance funds are usually lowinterest loans non-repayable if the project is a success.

The rules for spending the money are diverse. On a different basis operate business incubators, so popular on higher education facilities and created by special economic zones. The latter facilitates access to knowledge, office, software, etc. There is a wide range of opportunities for a future entrepreneur. An alternative to investors or sponsors are loans and credits for companies, however it is extreme taken into consideration many possibilities even such as Venture Capital 3 . Polakpotrafi.pl or other crowdfunding websites are a popular form of looking for investors on the Polish market. In the case of startups it is very often easier to find an investor through project promotion on crowdfunding websites. Halfway solution between crowdfunding and sponsoring is to offer shares in profit or shares in the company in return for the project support 4 . Additionally, it should be taken into consideration that without own capital to start a project implementation one may rarely find an investor who will not want something in return. More and more often it is possible to use online know-how of many organisations, business incubators, business chambers and associations, institutes of economic development in exchange for a share in the future profit of the company. Support offered by experienced entrepreneurs, businesspeople has diverse character, starting from organisational knowledge concerning economy, finances through marketing and on specialist knowledge from a given domain ending. Even if there are no particular amounts of money, this type of help is also valuated.

\footnotetext{
1 http://bestcapital.pl/czy-warto-inwestowac-w-startupy/ (July 22, 2015)

2 C. Klingbeil, T. Semrau (2017). For Whom Size Matters- The Interplay Between Incubator Size, Tenant Characteristics and Tenant Growth. Industry \& Innovation, 24 Issue 7, 735-736; L. Wang, F. Zhou, Y. An (2017). Determinants of Control Structure Choice Between Entrepreneurs and Investors in Venture Capital-Backed Startups. Economic Modelling, 63, 218

${ }^{3}$ T. Brown, E. Boon, L. Pitt (2017). Seeking Funding in Order to Sell: Crowdfunding as a Marketing Tool. Business Horizons, 60 Issue 2, 190

${ }^{4}$ https:/le-biznes.pl/jak-zalozyc-start-up-bez-srodkow-wlasnych/ (December 22, 2015)
} 
When creating startups without financial means it is not certain that they will not be needed in the future. Due to their online popularity, the majority of start-ups is totally cost-free. The only expense and investment is the idea, time and work put into the creation of virtual products such as mobile application, website, blog, service, etc. In the case of such activity it is always worth trying and observing to what extend the market will accept the offer and in which direction it will evolve. Then there is a chance for success because nothing important is missed. Perceiving market and recipients' behaviour for whom the start-up is designated, a bad idea may be abandon or alter so that it could fit the market.

It is worth emphasizing that as a rule at the beginning a startup does not have to be profitable. Profit is a derivative feature of a beginning enterprise. A model startup is a situation in which income zeroes out the expenses. If the entrepreneur is able to earn on a given project at the beginning it does not mean that in the following years they will not find any legal or economic obstacles. Ventures with non-established position reach the top as quickly as they fall down. Therefore, profits should be used for evolution and development, adjusting and improving the product. No one has ever created an ideal product or service which could not be improved ${ }^{1}$.

Analysing the number and state of startups in the world it is worth mentioning that in the Silicon Valley, the startup capital city of the world, between San Francisco Bay and San Jose, there are registered offices of such companies as: Apple, Facebook, Tesla, Intel, Lockheed Martin, HP, Google, Netfliks, eBay and many more other innovative firms which started their economic activity as startups. It is not possible to copy the Silicon Valley in a different part of the world but "bridges" may be built to facilitate the flow of know-how and capital. Israel deals with it really well. In Tel Aviv there are about thousand startups, one for each $19 \mathrm{~m}^{2}$. The biggest corporations such as IBM, Facebook, Google or Deutche Telekom have their corporate seats and research centres there and what is more there are many accelerators in the city, i.e. ventures helping a company in speeding its development. Almost every week there is an event for startups. Key role played Israeli government which in the ' 90 s decided to start Yozma programme. 10 Venture Capital funds were created, each with $20 \mathrm{~m}$ USD budget, investing in companies in the initial phase of development. Special tax conditions were offered to encourage foreign investors. In China, on the other hand, there is a fast growing percentage of people using different kinds of online services and mobile devices. China has its own equivalent of Google, eBay, Facebook and YouTube. $25 \%$ of the world's startups has been created and is operating there and their value is exceeding $1 \mathrm{bn} \mathrm{USD}^{2}$.

Korean start-ups develop equally rapidly, although a bit less spectacularly. Government is very helpful in this matter. Recently it has announced that Seul will spend almost 66bn USD to subsidize the activity of startups and innovative companies in the following years. Also in some regions local governments offer help. Young entrepreneurs may use the help of mentors owing to several dozens of accelerating programmes. Startup community has been growing since 2010 and the Silicon Valley seems to notice it. One of the most significant accelerator from the Silicon Valley -500 Start-ups has its representatives in Seul and offers not only 4-month mentoring programme but also invests in startups. More and more often to Korea go representatives of American funds ${ }^{3}$.

In Poland operate about 2.7 thousand start-ups. The majority manufactures software and offers its products and services to companies. European research show that Polish startups are rather new - average time of operation does not exceed 2 years. This put Poland on the third place in Europe regarding the youngest enterprises, right behind Romania (1.3 years) and Italy (1.7 Years). Polish startups are in majority young companies at an early stage of identifying customers' needs and are mostly created with subsidies from European funds ${ }^{4}$.

The majority of startups (77\%) conducts its sale in Business to Business model (B2B). In this group there are also startups which sell to companies and individual clients, i.e. they implement mixed model $(26 \%)$. As a result it might be stated that "pure" B2B model implements half of the researched entities and 18\% sells only in the Business to Consumer model (B2C). Start-ups from category "other" realize variations of the models mentioned (B2B2C, B2G, etc.). It is worth noticing that every third researched start-up offers its services in the popular SaaS model (Software as a Service) and more importantly the majority $(59 \%)$ is micro-entities. More than $3 / 4$ sells to business and only half of them offers its products or services to big companies, including huge corporations. Additionally, over $47 \%$ of startups are exporters who conduct foreign sell since

\footnotetext{
${ }^{1}$ http://businessinsider.com.pl/finanse/firmy/startupowe-stolice-gdzie-powstaja-startupy/6e74kt4 (May 29, 2016)

2 http://businessinsider.com.pl/finanse/firmy/startupowe-stolice-gdzie-powstaja-startupy/6e74kt4 (May 29, 2016)

${ }_{3}$ A. Skala, E. Kruczkowska (2017). Raport. Polskie startupy 2016. Warszawa: Bank Citi Handlowy, 8, 11, 24-25, 52

${ }^{4}$ D. Acemoglu, P. Aghion, R. Griffith, F. Zilibotti (2007). Vertical Integration and Technology: Theory and Evidence, Institute for Empirical Research in Economics University of Zurich. Working Paper Series, 342, 2
} 
the beginning of their activity. Therefore, there is a polarization of the group of exporting startups: first numerous group exports a lot and the second group, i.e. in majority micro-entities, not much. The least is exporters who balance the sale on domestic and foreign market, $54 \%$ exports to EU countries, $3 \%$ of them exports to Asia and only $1 \%$ to Russia what is understandable in connection with embargo put on Poland by Russia as well as Russia-Poland relations.

To sum up the above considerations, it should be firmly stated that the process of building startups is not easy. The biggest problem is the lack of funds for development. There is also the lack of faith in success what is partly connected with no ability to connect interesting and innovative ideas with good marketing. Additionally, especially Polish startups cooperate with big corporations in a very small degree, what will be discussed in the further part of this article.

\section{Tools supporting starups development all over the world}

There are a lot of tools supporting startups development not only in Poland but worldwide. Two of them need to be emphasised: cooperation and coopetition, completing each other. Cooperation which is broadly defined collaboration helps in making contacts between start-ups created by micro-entities and big, international corporations. Such economic entities are able to teach big companies a lot about creativity and ingenuity. Coopetition results from simultaneous clash of two contrary relation: competition and cooperation. The process of establishing cooperation between the researched entities in inseparably accompanied by broadly understood competitiveness which induces to implement innovative solutions used by both new startups as well as big concerns or holdings.

\subsection{Cooperation as a determinant influencing the process of establishing active start-ups}

Enterprises starting their economic activity to function efficiently need not only proper resources management, elaborated budget or proper finances control but also good communication, fluidity between particular departments and different size entities. To do so they need to elaborate cooperation strategy consisting in technological and organisational connection of production and distribution with sales or other processes connected with startup functioning.

Many experts from economy and finances believe that technological advance and globalisation contribute to internal organisation of a company. In this case smaller companies are favoured because they seem to be more flexible compared to big entities. Small and medium-size enterprises have in particular the possibility to increase the level of innovation due to cooperation with big corporations on a global scale ${ }^{1}$.

With reference to the above, the influence of cooperation on the development and through this on the activity of startups is researched with regard to employment, innovation, profitability, the number of clients and business partners. The data concerning arithmetic mean, median and standard deviation is presented in the table below (Table 1)

Table 1. The influence of cooperation on the startups development in 2010-2017

\begin{tabular}{|c|c|c|c|c|c|c|}
\hline & Country & $\begin{array}{l}\text { Increase of } \\
\text { employment level }\end{array}$ & $\begin{array}{l}\text { Increase of } \\
\text { innovation level }\end{array}$ & $\begin{array}{l}\text { Profitabilit } \\
\text { y }\end{array}$ & $\begin{array}{l}\text { Increase of the number of } \\
\text { clients }\end{array}$ & $\begin{array}{l}\text { Increase of } \\
\text { the } \\
\text { number of } \\
\text { business } \\
\text { partners }\end{array}$ \\
\hline $\begin{array}{l}\text { MEAN case 1- } \\
189\end{array}$ & Lesotho & 0.71957672 & 0.396825397 & $\begin{array}{l}0.433862 \\
434\end{array}$ & 0.582010582 & $\begin{array}{l}0.6613756 \\
61\end{array}$ \\
\hline $\begin{array}{l}\text { MEDIAN case } \\
1-189\end{array}$ & Lesotho & 1 & 0 & 0 & 1 & 1 \\
\hline SD case 1-189 & 54.7037476 & 0.45039915 & 0.490538649 & $\begin{array}{l}0.496922 \\
874\end{array}$ & 0.494538448 & $\begin{array}{l}0.4744988 \\
53\end{array}$ \\
\hline VALID_N case & Kosovo & 189 & 189 & 189 & 189 & 189 \\
\hline
\end{tabular}

\footnotetext{
${ }^{1}$ M. Bengtsson, S. Kock (2000). „Coopetition” in Business Networks- Cooperate and Compete Simultaneously. Industrial Marketing Management, 29, 411-426; J. Cygler (2009). Kooperencja przedsiębiorstw. Czynniki sektorowe i korporacyjne. Warszawa: Szkoła Główna Handlowa, p. 15-16; A. Ejsmont (2016). The Deliveries Chain and Value Added in Context of Coopetition Between The Service and Industrial Companies in Poland and UE. European Journal of Economics and Business Studies, 6, 201
} 


\begin{tabular}{|c|c|c|c|c|c|c|}
\hline 1-189 & & & & & & \\
\hline $\begin{array}{l}\text { SUM case 1- } \\
189\end{array}$ & 36855 & 136 & 75 & 82 & 110 & 125 \\
\hline MIN case $1-189$ & Afghanistan & 0 & 0 & 0 & 0 & 0 \\
\hline MAX case $1-189$ & Zimbabwe & 1 & 1 & 1 & 1 & 1 \\
\hline $\begin{array}{l}25 \text { th } \% \text { case } 1- \\
189\end{array}$ & $\begin{array}{l}\text { Dominican } \\
\text { Republic }\end{array}$ & 0 & 0 & 0 & 0 & 0 \\
\hline $\begin{array}{l}-75 \text { th } \% \text { case } 1- \\
189\end{array}$ & San Marino & 1 & 1 & 1 & 1 & 1 \\
\hline
\end{tabular}

Explanation: 1- affects, 0-does not affect

Source: Own elaboration on the basis of Doing Business. Equal Opportunity for All (2017). Washington: A World Bank Group Flagship Report, 114-117, 188-192; http://ec.europa.eu/eurostat/data/database (September 9, 2017)

Based on the data from Table 1 it may be firmly stated that in such countries as Lesotho, Kosovo, Afghanistan, Zimbabwe, Dominica Republic and San Marino the influence of cooperation on the development of startups had significant importance with regard to the level of employment, innovation, profitability, the number of clients and business partners. However, countries such as the USA, Switzerland, Japan or even China were characterised by increased level of cooperation on the above factors. In these countries the biggest number of startups were registered and at the same time these countries have enhanced level of innovation and as a result profitability, increased level of employment, number of clients and business partners growing every year. Additionally, the analysis and synthesis of this material indicated that in these countries broadly understood cooperation on a massive scale has been developing between big corporations and smaller startups.

With reference to the above, taken into consideration the data concerning the influence of cooperation on the development of start-ups all over the world in 2010-2017 in the context of increasing employment, level of innovation and profitability as well as the number of customers and consequently the number of business partners, to research the influence of cooperation on the above factors $t$-test was conducted for dependent trials where two dependencies were compared: the level of innovation and profitability as well as the number of employed, customers and business partners. The data are presented in Graph 1 (Graph 1).

Graph 1. Dependence of standardised effect on cooperation among startups in 2010-2017

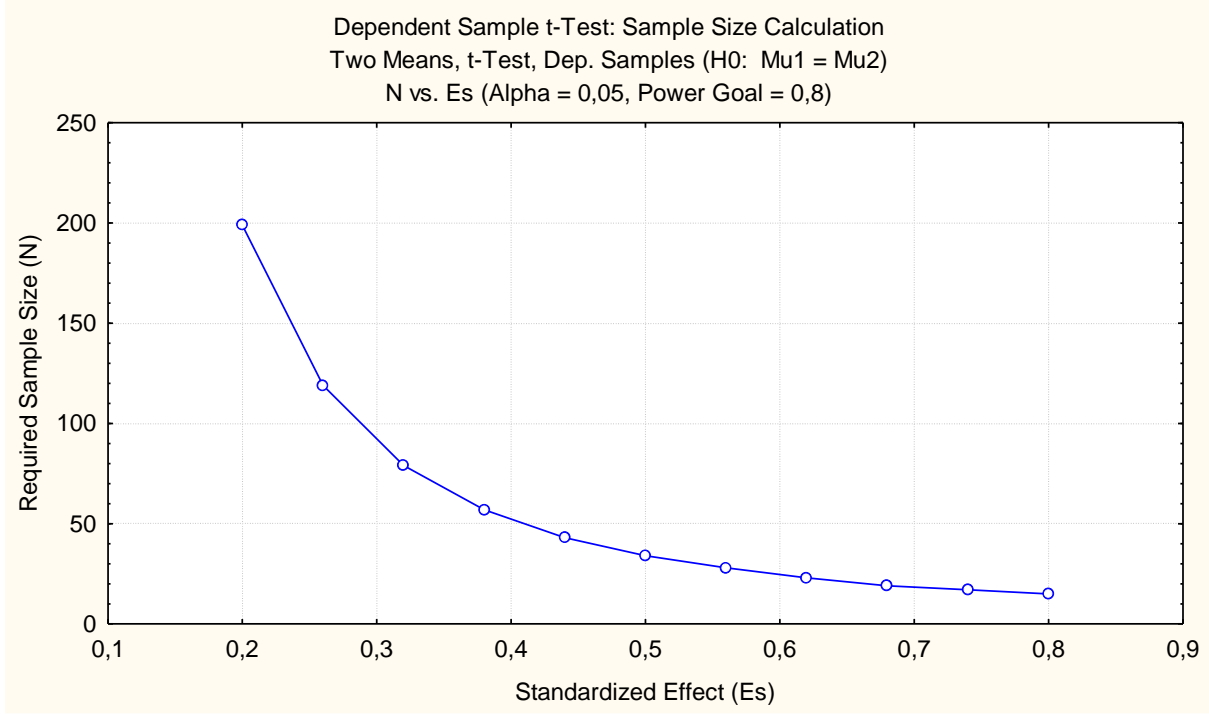


Source: Own elaboration based on Doing Business. Equal Opportunity for All (2017). Washington: A World Bank Group Flagship Report, 114-117, 188-192; http://ec.europa.eu/eurostat/data/database (September 9, 2017)

In the context of testing statistical relevance, a null hypothesis was formulated stating that cooperation with big corporations does not influence development increase of generally smaller startups in the context of enhancing employment, innovation level, profitability as well as the number of customers and business partners, what is opposite to what the author wanted to demonstrate. In the analysed case, very small standardised effect amounting to 0,00106482 with the power of test for the required sample size $\mathrm{N}=188$ on the level of 0.8000 confirms the reliability of alternative hypothesis stating that the condition to increase the influence of cooperation on the development of startups all over the world is intensified cooperation of the researched entities with big corporations.

\subsection{Coopetition as a determinant influencing the process of establishing active startups}

There is no unequivocal definition of coopetition in the strategic management literature. Mostly quoted is M. Bengtsson and S. Kock's definition in which coopetition is a simultaneous relation of competition and cooperation appearing between competitors. This paradox causes that at least two independent parties cooperate with each other in order to achieve common benefits and do not stop being competitors. The complexity of cooperation and competition results from simultaneous application of contradictory relations between enterprises consisting in trust and conflict. As a consequence, there is a paradox in which competing sides need to trust each other, engaging in cooperation, sharing information, experience and cooperation risk. Owing to this both parties may integrate their actions to achieve intended benefits and at the same time realise individual strategic aims ${ }^{1}$. Simultaneousness of these two phenomena of competition and cooperation also causes interdependence of their relations. Therefore, competitors cooperate in some functions of the value chain, i.e. common production, marketing, $B+R$, information systems but they compete in others, such as customer service of products offer. Another element of M. Bengtsson and S. Kock's definition is the competitive character of both parties. This means that coopetition concerns relation of direct competitors who very often offer similar groups of products or whose offer is addressed to the same customers regarding demand and geography.

With reference to the above, the influence of coopetition on the development and at the same time on the activity of startups worldwide regarding employment, innovation, profitability, the number of customers and business partners was researched on the basis of analysis and synthesis. The data concerning arithmetical mean, median and standard deviation is presented in the table below (Table 2).

Table 2. The influence of coopetition on the development of startups in 2010-2017

\begin{tabular}{|c|c|c|c|c|c|c|}
\hline & Country & $\begin{array}{l}\text { Increase of the level } \\
\text { of employment }\end{array}$ & $\begin{array}{l}\text { Increase of the level } \\
\text { of innovation }\end{array}$ & $\begin{array}{l}\text { Profitab } \\
\text { ility }\end{array}$ & $\begin{array}{l}\text { Increase of the } \\
\text { number of customers }\end{array}$ & $\begin{array}{l}\text { Increase of the number of } \\
\text { business partners }\end{array}$ \\
\hline $\begin{array}{l}\text { MEAN case } \\
1-189\end{array}$ & Lesotho & 0.71957672 & 0.396825397 & $\begin{array}{l}0.4338 \\
62434\end{array}$ & 0.428571429 & 0.582010582 \\
\hline $\begin{array}{l}\text { MEDIAN } \\
\text { case 1-189 }\end{array}$ & Lesotho & 1 & 0 & 0 & 0 & 1 \\
\hline $\begin{array}{l}\text { SD case } 1- \\
189\end{array}$ & 54.7037476 & 0.45039915 & 0.490538649 & $\begin{array}{l}0.4969 \\
22874\end{array}$ & 0.496186062 & 0.494538448 \\
\hline $\begin{array}{l}\text { VALID_N } \\
\text { case } 1-189\end{array}$ & Kosovo & 189 & 189 & 189 & 189 & 189 \\
\hline $\begin{array}{l}\text { SUM case } \\
1-189\end{array}$ & 36855 & 136 & 75 & 82 & 81 & 110 \\
\hline $\begin{array}{l}\text { MIN case 1- } \\
189\end{array}$ & Afghanistan & 0 & 0 & 0 & 0 & 0 \\
\hline $\begin{array}{l}\text { MAX case } 1- \\
189\end{array}$ & Zimbabwe & 1 & 1 & 1 & 1 & 1 \\
\hline 25th\% & Dominican & 0 & 0 & 0 & 0 & 0 \\
\hline
\end{tabular}

1 Sala, Shpëtim: Italian-Albanian-Greek Dictionary (Transliteration and Albanian Dictionary ) II, West Print, Tiranë, 2013. 


\begin{tabular}{|l|l|l|l|l|l|l|}
\hline case $1-189$ & Republic & & & & & \\
\hline $\begin{array}{l}75 \text { th } \% \\
\text { case } 1-189\end{array}$ & San Marino & 1 & 1 & 1 & 1 & 1 \\
\hline
\end{tabular}

Explanation: 1- affects, 0 - does not affects

Source: Own elaboration on the basis Doing Business. Equal Opportunity for All (2017). Washington: A World Bank Group Flagship Report, 114-117, 188-192; http://ec.europa.eu/eurostat/data/database (September 9, 2017)

On the basis of the data included in Table 2 it may be firmly stated that in such countries as: Lesotho, Kosovo, Afghanistan, Zimbabwe, Dominican Republic and San Marino the influence of coopetition on the development of startups, similarly as previously researched influence of cooperation, was significant with regard to the level of employment, innovation, profitability, the number of customers and business partners. On the other hand, countries such as: the USA, Switzerland, Japan or even China were characterised by increased level of coopetition on the above factors. In these countries the biggest number of startups were registered and at the same time these countries have enhanced level of innovation and as a result profitability, increased level of employment, number of clients and business partners growing every year. Additionally, the analysis and synthesis of this material indicated that in these countries broadly understood cooperation on a massive scale has been developing between big corporations and smaller start-ups.

With reference to the above, taken into consideration the data concerning the influence of coopetition on the development of startups worldwide in 2010-2017 in the context of increasing employment, level of innovation and profitability as well as the number of customers and consequently the number of business partners, to research the influence of coopetition on the above factors, using Statistica programme, $t$-test was conducted for dependent trials where two dependencies were compared in the same way as in the case of cooperation. The data is presented in the graph below (Graph 2)

Graph 2. Dependence of standardised effect on coopetition among startups in 2010-2017

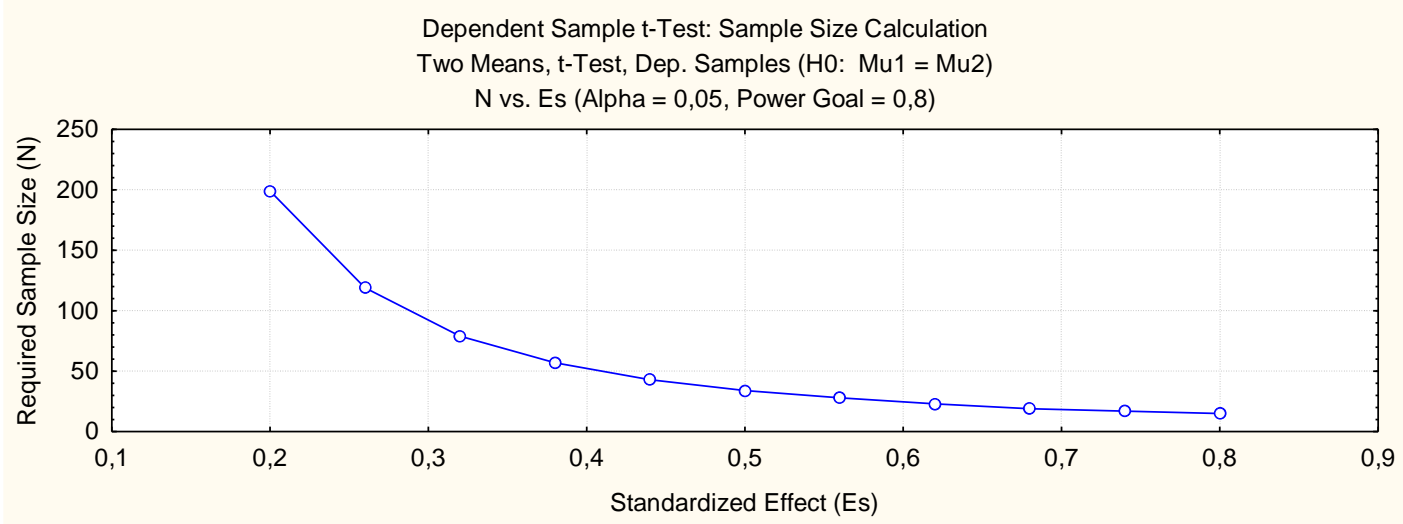

Source: Own elaboration on the basis of Doing Business. Equal Opportunity for All (2017). Washington: A World Bank Group Flagship Report, 114-117, 188-192; http://ec.europa.eu/eurostat/data/database (September 9, 2017)

In the context of testing statistical relevance a null hypothesis was formulated stating that coopetition with big corporations does not influence development increase and at the same time the activity of generally smaller start-ups in the context of enhancing employment, innovation level, profitability as well as the number of customers and business partners, what is opposite to what the author wanted to demonstrate. In the analysed case, very small standardised effect amounting to 0.00251692 with the power of test for the required sample size $\mathrm{N}=188$ on the level of 0.8000 confirms the reliability of alternative hypothesis stating that the condition to increase the influence of coopetition on the development of startups worldwide is intensified cooperation of the researched entities with big corporations.

\section{Summary}


When conducting business activity, a young company faces many legal and economic difficulties which have impact on such aspects as: the level of employment and innovation, generally understood profitability connected with achieving profits of making loss, increased or decreased number of customers and consequently business partners. Therefore, the tool which could help new startups in their activity on international markets is cooperation and coopetition. The lack of the possibility to finance the activity from the beginning, lack of including in the business plan innovative ideas and necessity to intensely promote products or services are the most common problems which startups around the world have to deal with on a daily basis. Cooperation connected with coopetition is to facilitate the start to the researched entities by broadly understood cooperation interlaced with competing with big, international corporations.

With reference to the above, on the basis of analysis and synthesis of collected material, the influence of cooperation and coopetition on the development and at the same time the activity of startups worldwide was researched with regard to employment, innovation, profitability, the number of customers and business partners. The conducted research firmly indicate that in such countries as Lesotho, Kosovo, Afghanistan, Zimbabwe, Dominican Republic and San Marino the influence of cooperation and coopetition on the development of startups was very significant regarding the above mentioned factors. However, such countries as the USA, Switzerland, Japan or even China were characterised by bigger influence of both types of tools facilitating start-ups activity on the above factors, all the more that these countries have the biggest number of startups and at the same time they have increased level of innovation and consequently profitability, increased level of employment and growing number of customers and business partners.

$T$-test for dependent trials was conducted, using Statistica, in which two dependencies were compared: the level of innovation and profitability as well as the number of employed, customers and business partners. In the context of testing statistical relevance a null hypothesis was formulated stating that cooperation connected with coopetition with big corporations does not influence the development increase of generally smaller startups in the context of enhancing employment, innovation level, profitability as well as the number of customers and business partners, what is opposite to what the author wanted to demonstrate. In both analysed cases standardized effect was very small what confirmed the reliability of alternative hypothesis stating that the condition to increase the influence of cooperation and coopetition on the development of startups worldwide is intensified cooperation of the researched entities with big corporations. However, the influence of coopetition on startups activity was bigger than in the case of cooperation because the value of the standardised effect was higher and amounted to 0.00251692 whereas in the case of cooperation it was only 0.00106482 . With reference to the above, the conclusion is that competition connected with broadly understood cooperation becomes a bigger motivator in the development of economic activity conducted by startups all over the world.

\section{Bibliography}

[1] Acemoglu D., Aghion P., Griffith R., Zilibotti F. (2007). Vertical Integration and Technology: Theory and Evidence, Institute for Empirical Research in Economics University of Zurich. Working Paper Series, 342.

[2] Bengtsson M., Kock S. (2000). Coopetition in Business Networks- Cooperate and Compete Simultaneously. Industrial Marketing Management, 29.

[3] Brown T., Boon E., Pitt L. (2017). Seeking Funding in Order to Sell: Crowdfunding as a Marketing Tool. Business Horizons, 60 Issue 2.

[4] CyglerJ. (2009). Kooperencja przedsiębiorstw. Czynniki sektorowe i korporacyjne. Warszawa: Szkoła Główna Handlowa w Warszawie.

[5] Doing Business. Equal Opportunity for All (2017). Washington: A World Bank Group Flagship Report.

[6] Ejsmont A. (2016). The Deliveries Chain and Value Added in Context of Coopetition Between The Service and Industrial Companies in Poland and UE. European Journal of Economics and Business Studies, 6.

[7] Klingbeil C., Semrau T. (2017). For Whom Size Matters- The Interplay Between Incubator Size, Tenant Characteristics and Tenant Growth. Industry \& Innovation, 24 Issue 7.

[8] Picken J. (2017). From Startup to Scalable Enterprise: Laying the Foundation. Business Horizons, 60 Issue 5.

[9] Rockowood K. (2017). Is That Startup Spirit Sagging? You Can Build it Back Up. Inc, 39 Issue 7. 
[10] Skala A., Kruczkowska E. (2017). Raport. Polskie startupy 2016. Warszawa: Bank Citi Handlowy.

[11] Wang L., Zhou F., An Y. (2017). Determinants of Control Structure Choice Between Entrepreneurs and Investors in Venture Capital-Backed Startups. Economic Modelling, 63.

[12] http://bestcapital.pl/czy-warto-inwestowac-w-startupyl (July 22, 2015).

[13] http://businessinsider.com.pl/finanse/firmy/startupowe-stolice-gdzie-powstaja-startupy/6e74kt4 (May 29, 2016).

[14] https://e-biznes.pl/jak-zalozyc-start-up-bez-srodkow-wlasnych/ (December 22, 2015).

[15] http://ec.europa.eu/eurostat/data/database (September 9, 2017).

[16] www.obserwatorfinansowy.pl/forma/rotator/usa-korporacje-z-rekordowymi-zyskami-startupy-odbijaja-powoli/ (February 9, 2015).

[17] http://www.statsoft.pl/textbook/glosfra_stat.html?http\%3A\%2F\%2Fwww.statsoft.pl\%2Ftextbook\%2Fglose.html (August 12, 2016). 